\title{
Affective and Cognitive Theory of Mind in Children With Intellectual Disabilities: How to Train Them to Foster Social Adjustment and Emotion Regulation?
}

\author{
Emilie Jacobs ${ }^{1} \&$ Nathalie Nader-Grosbois ${ }^{1}$ \\ ${ }^{1}$ Psychological Sciences Research Institute, Chair Baron Frère in special education, UCLouvain, Belgium \\ Correspondence: Nathalie Nader-Grosbois, Psychological Sciences Research Institute, UCLouvain, 10 Place Cardinal \\ Mercier, 1348 Louvain-la-Neuve, Belgium.
}

Received: Dec. 18, 2019

Accepted: Feb. 23, 2020

Online Published: Mar. 11, 2020

doi:10.11114/jets.v8i4.4757

URL: https://doi.org/10.11114/jets.v8i4.4757

\begin{abstract}
Affective and cognitive Theory of Mind (ToM) is known to be deficit or delayed in children with intellectual disabilities (IDs), when compared with typically developing children matched for developmental age. Yet, little is known about causal contribution of affective and cognitive ToM on emotion regulation or social adjustment in these children. Studies that aimed to answer this problematic, implemented training focusing on the nine mental states - mainly on beliefs and emotions - and in toddlers and adolescents' samples, rarely compared to control group. The present study aims at testing whether training ToM abilities notably affective and cognitive mental states in children with IDs could foster ToM, but also their emotion regulation and social adjustment. 30 children with mild or moderate IDs functioning at preschool developmental age, took part in a pre-test session involving measures on cognition and ToM. Teachers and/or parents completed questionnaires evaluating children's emotion regulation and social adjustment. Secondly, children were allocated to control or experimental group which benefits from the specific "ToM program for children". It was delivered in eight sessions, by an experimented searcher to sub-groups of three children. Finally, all children took part in a post-test session. Results showed significant improvement of affective and cognitive ToM abilities in children with IDs in experimental groups. After ToM training, they displayed a better understanding of cognitive mental states and of consequences of emotions. In post-tests, they are perceived as more socially adjusted by teachers.
\end{abstract}

Keywords: theory of mind, training, intellectual disabilities, emotion regulation, social adjustment

\section{Introduction}

Children with intellectual disabilities are known to have limitations in emotional and social competence (American Association on Intellectual and Developmental Disabilities; AAIDD, 2011). Due to these difficulties, they are more likely to have deficits in emotion regulation, of displaying social maladjustment or behavioral disorders, frequently reported by parents, teachers, specialized educators and psychologists (Baurain \& Nader-Grosbois, 2013; Charman \& Campbell, 2002; Dekker \& Koot, 2003; Fiasse \& Nader-Grosbois, 2012; Giaouri, Alevriadou, \& Tsakiridou, 2010; Leffert \& Siperstein, 2002). In order to foster their social inclusion, it is essential to prevent these difficulties as much as possible.

To explore their emotional and social profile, we could explore the potential causal role of their specific Theory of mind (ToM) abilities. ToM corresponds to abilities to understand one's own and other people's mental states, including beliefs, emotions, intentions, desires, false beliefs, pretense, knowledge, thinking, visual perception, and attention (Flavell, 1999). The ability to infer other's mental states leads to understanding and predicting social behavior and to respond in socially adaptive ways (Barisnikov, Van der Linden, \& Detraux, 2002; Deneault \& Ricard, 2013; Denham et al., 2003). ToM competences therefore help to foster positive social interactions with peers or adults, and adjustment in daily life. Recently, there has been an interest in differentiating "affective" and "cognitive" ToM (Hynes, Baird, \& Grafton, 2006; ShamayTsoory et al., 2007). Affective ToM is associated with the understanding of desire and emotions while cognitive ToM is related to understanding of the other mental states. To evaluate the affective and cognitive dimensions, several authors (e.g., Hutchins, Bonazinga et al., 2008; Hutchins, Prelock et al., 2012) have created new measures, namely the ToM task Battery and the Theory of Mind Inventory, to assess a broader range of mental states. There are several prerequisites to developing ToM abilities, such as joint attention (Charman et al., 2000; Tourrette, Recordon, Barbe, \& Soares-Boucaud, 2000), imitation (Meltzoff, 2002), pretend play (Barthélémy \& Tartas, 2009; Rakoczy, 2008) or empathy (Astington, 2003) 
are needed. According to a Vygotskian perspective, children develop ToM abilities through language acquisition and social interactions, most notably during conversations in the family, social and cultural environment (Ricard, Cossette, \& Gouin Décarie, 1999). Children with intellectual disabilities (IDs) display difficulties in these prerequisite factors and in ToM abilities themselves. Two kind of hypotheses have emerged regarding ToM abilities in these children. Empirical studies have observed either a delay or a deficit: (1) In comparison to typically developing children matched for developmental age, children with IDs present a delay in their understanding of causes and consequences of emotions (Baurain \& Nader-Grosbois, 2013; Fiasse \& Nader-Grosbois, 2012; Garitte, 2003; Thirion-Marissiaux \& Nader-Grosbois, 2008c). (2) Results support either a delay (Fiasse \& Nader-Grosbois, 2012; Giaouri et al., 2010), or a deficit (Charman \& Campbell, 2002; Thirion-Marissiaux \& Nader-Grosbois, 2008c) in these children's understanding of beliefs, depending on the measure used. Notably, children with borderline IDs have displayed difficulties in distancing themselves from their own perspective, wherein they do not differentiate their knowledge from the knowledge of others (Baglio et al., 2016).

A number of ToM trainings have been created and tested with children with (1) autistic spectrum disorders (e.g. Gevers, Clifford, Mager, \& Boer, 2006; Hadwin, Baron-Cohen, Howlin, \& Hill, 1996; Howlin, Baron-Cohen, \& Hadwin, 2011; McGregor, Whiten, \& Blackburn, 1998; Paynter \& Peterson, 2013; Ratcliffe, Wong, Dossetor, \& Hayes, 2014; Serret et al., 2014; Swettenham, 1996; Wellman et al., 2002; Williams, Gray, \& Tonge, 2012), (2) externalizing behavior (e.g. Houssa, Jacobs, \& Nader-Grosbois, 2016; Houssa \& Nader-Grosbois, 2016; Shure, 1993; Webster-Stratton \& Hammond, 1997), or (3) IDs (e.g. Jacobs, Léonard, Nader-Grosbois, Houssa, \& Mazzone, 2016; Lachavanne \& Barisnikov, 2013; Stewart \& Singh, 1995). Several issues emerged from these studies among samples of participants with IDs or autism spectrum disorders (see appendixes A and B). It can be seen that very few samples consisted of children functioning at a preschool developmental age. Quasi-experimental studies have rarely included a control group. Training targets and measures focused on emotions and beliefs and not on all the cognitive and affective mental states. They generally used visual material supports such as photographs, pictures, mirror, stories or videos. Techniques implemented were corrective feedback, repetition, discussions, role-play, questions, key concepts, narratives, and storytelling (e.g. Lachavanne \& Barisnikov, 2013; Paynter \& Peterson, 2013; Ratcliffe et al., 2014; Serret et al., 2014; Stewart \& Singh, 1995; Wellman et al., 2002). Most of these trainings have resulted in positive effects on ToM abilities. Children improved most in terms of their understanding of beliefs, false beliefs and emotions. Several studies indicated a better recognition of facial emotion expression, which is the first step of understanding the cause and consequences of emotions. Some trainings have also demonstrated positive effects on social problem-solving skills, emotion regulation or behavioral problems. In their meta-analysis, Hofmann and colleagues (2016) demonstrated that this kind of training in ASD and typically developing population is working well in a range of contexts (with a large effect size). Although these results are encouraging, they give little information about the potential causal contributions of affective and cognitive ToM abilities on emotion regulation and social adjustment, especially in children with IDs functioning at a preschool developmental age. Therefore, the goal of the present study is to test this causal contribution of affective and cognitive ToM abilities on emotion regulation and social adjustment. To do so, a new ToM training will be implemented in children with mild to moderate IDs. To assess its effectiveness, performance-based measures and questionnaires evaluating ToM and socio-emotional abilities will be administrated before and after training.

\section{Method}

\subsection{Participants}

Children included 23 boys and 7 girls with mild to moderate non-specific IDs. Recruitment was done with special education primary schools, from French speaking areas of Belgium. They have a mean age of 106.87 months (SD =19.85), between 56 and 145 months. Children's IQ levels range from 50 and 75 and they have been previously diagnosed as having intellectual disabilities, according to AAIDD and DSM-V criteria. These children display limitations in intellectual functioning and in adaptive behavior. Children present a global developmental age (GDA) ranging from between 40 and 88 months $(M=62.57, S D=14.26)$. Moreover, a verbal GDA is estimated between 37 and 86 months $(M=61.43 ; S D=$ 14.38). The recruitment and the sample were restricted due to very strict inclusion criteria - the children's developmental age corresponds to preschool age; consent given by schools, teachers and parents, notably to record videos of each training session; parents and teachers invest time to complete each questionnaire at pre-tests and -post-tests. Based on the exclusion criteria, children with Williams's syndrome or Autism spectrum disorder could not be included, as well as children who are not able to express sentences of three to four words. Moreover, 10 participants left the research program, leading to a mortality rate in the sample.

\subsection{Measures}

\subsubsection{Wechsler Preschool and Primary Scales (WPPSI-III; Wechsler, 2004)}

This measure gives information about the cognitive functioning and the child' GDA. It was used only in pretesting because it allowed screening for the inclusion criteria (i.e., mild to moderate intellectual disability and a GDA between 3 and 7 
years). Four subtests were administered. Two verbal ("information" and "vocabulary") and two non-verbal ("block design" and "matrix reasoning") subscales, that strongly correlated with total WPPSI-III scores, were used.

\subsubsection{Tom-Emotions Tasks (Thirion-Marissiaux \& Nader-Grosbois, 2008b)}

Computerized ToM-emotions tasks (E-prime) evaluate the comprehension of emotions, and particularly their causes and consequences. Each child completed three tasks. (1) The first one was a preliminary task of facial emotional expression (FEE) recognition, in which the child is required to recognize joy, sadness, anger, and fear in pictures. (2) The second task evaluated the comprehension of the causes of emotions. Four stories, with the same beginning, were presented to the child who had to predict the protagonist's emotion according to the end of the script and justify his or her response. The correct emotion is scored 1 point and a coherent justification is scored 0.5 , with a maximum score of 6. (3) The third task estimated the understanding of consequences of emotions. Four scripts, eliciting joy, anger, sadness and fear, were presented to the child. After listening to the beginning of each story, the child had to infer the protagonist's behavior. He or she chooses from among three responses, illustrating a socially adjusted, a maladjusted or a neutral behavior, and justified his or her choice. The choice of socially adjusted cards scored 1 , whereas the maladjusted or neutral score 0 . A coherent justification scored 0.5 , with a maximum of 6 . ToM-emotions tasks are summed for a possible maximum score of 12 .

Concerning validation data, factor analysis revealed two subscales (causes and consequences). Cronbach's alpha was .57, and the test-retest stability was significant for the two subscales (between .56 and .68). The validation is good and it has been tested in typically developing children and children with IDs.

\subsubsection{ToM-Beliefs Tasks (Thirion-Marissiaux \& Nader-Grosbois, 2008a)}

The ToM-beliefs tasks assesses the understanding of beliefs, through five tasks: (1) Deception skills task (Oswald \& Ollendick, 1989); (2) Change of representation task (Flavell, Everett, Croft, \& Flavell, 1981); (3) Appearance-Reality task (Flavell, 1986); (4) Unexpected content task (Perner, Leekam, \& Wimmer, 1987); (5) Change of location task (Wimmer \& Perner, 1983). Each task scores 1 point, with a possible maximum score of 5. During the task validation process, the inter-judge agreement was very high (between 99\% and 100\%; Cohen's kappa between .98 and .99; Pearson correlation coefficient between .99 and 1). No difference between the test and retest session was obtained. These ToMbeliefs tasks were validated with children with IDs.

2.2.4 ToM-Task Battery-French Version (Hutchins, Bonazinga, Prelock, \& Taylor, 2008; Nader-Grosbois \& Houssa, 2016)

This battery estimates children's ToM abilities about differentiated mental states. Nine tasks evaluate: (1) Emotion recognition; (2) Perspective taking; (3) Inference of desire-based emotion; (4) Inference of perception-based belief; (5) Inference of perception-based action; (6) False belief; (7) Inference of Belief- and Reality-Based Emotion and Second Order Emotion Task; (8) Message-Desire Discrepant; (9) Second-Order False Belief. The child is asked different questions: control, test and prompt questions. Each correct test question is scored 1, with a maximum total score of 15 . This measure also provides sub-scores relating to affective, cognitive or mixed mental states. Concerning validation, the Cronbach's alpha demonstrated good reliability $(\alpha=.91)$, which has been validated with children with atypical development.

2.2.5 Theory Of Mind Inventory - French-Version (Tomi-Vf; Houssa, Mazzone, \& Nader-Grosbois, 2014; Hutchins, Prelock, \& Bonazinga, 2012)

This questionnaire assesses parents' perceptions of their child's ToM abilities used in daily life. On 39 items, parents evaluate the child's comprehension of nine mental states: desires, emotions, beliefs, intentions, attention, perception, thinking, pretense, knowledge. Each item is scored out of 20 and a maximum total score of 20 is obtained by averaging item scores. The 3 sub-scores relate to cognitive mental states, socio-emotional mental states and intentions and beliefs. Validation data of the french version match those of the original version (Hutchins et al., 2012), demonstrating good internal consistency $(\alpha=.94)$ and test-retest reliability $(r=.86)$.

2.2.6 Emotion Regulation Checklist - French Version (ERC, Shields \& Cicchetti, 1997; ERC-Vf, Nader-Grosbois \& Mazzone, 2015)

This questionnaire assesses the parents' perception about their child's emotional regulation ability. This measure is applicable for children aged from 3 to 12 years old with or without development disorder. Using a 4-point Likert scale, ranging from never to usually, parents evaluate the occurrence of specific behaviors. Parents completed the questionnaire, estimating the child's emotion regulation with 8 items and emotion dysregulation with 16 items. Emotion regulation relates to appropriate empathy, affective displays, emotional and frustration control while emotion dysregulation is linked to mood lability, angry reactivity and dysregulated negative affect. Emotional regulation and dysregulation scores were summed to provide a composite emotional regulation score. Factor analysis for the french version of this questionnaire identified two factors, namely "emotional regulation" and "emotional dysregulation". During a validation process, the 
inter-judge agreement was carried out and was high for the two scales $(88 \%$ for emotional regulation and $86 \%$ for emotional dysregulation). Regarding reliability, analyses revealed a good intern consistency $(\alpha=.70)$.

\subsubsection{Social Adjustment Scales for Children (EASE; Hughes, Soares-Boucaud Hochman \& Frith, 1997)}

This questionnaire measures social adjustment with 50 items completed by parents, which estimate their child's socioemotional adjustment, by rating the frequency of daily interaction related behavior on a 2-point Likert scale. One-half of items assess behavior relating to politeness, discipline or civility and gives an "EASE - Social skills" score. The other half evaluate social skills relating to Theory of Mind competencies, considering others' emotions, desires or beliefs, and provides an "EASE - ToM" score. The maximum score is 100. The "EASE - Social skills" and "EASE - ToM" scores demonstrate good reliability (respectively $\alpha=.77$ and $\alpha=.79$; Hughes, Soares-Boucaud, Hochmann, \& Frith, 1997).

\subsubsection{Child Behavior Checklist (CBCL; Achenbach, 1991)}

This measure assesses children's behavioral and emotional problems, and includes 79 items. For each item, parents indicate the frequency of children's behavior on a 3-point Likert scale - from "not at all present" to "often present". Two scores are obtained: one relating to internalizing behavior and the other externalizing behavior. "Attention problems" and "aggressive behavior" subscales are summed to obtain the externalizing behavior score (clinical cutoff $>24$ ) and "anxious/depressed", "emotionally reactive", "withdrawn" and "somatic complaints" subscales are summed to obtain the internalizing behavior score (clinical cutoff $>17$ ). Using clinical cutoffs, profiles in terms of behavioral and emotional problems are identified in the present sample at baseline. Cronbach's alphas for the different subscales are between .63 and .86 .

\subsection{Procedure}

This study was approved by an ethical committee and the consent of parents and their child were obtained before proceeding. All of the measures described above were administered in the pretest session. Children were then randomly assigned to an experimental or a control group. No difference was found between these two groups on pretest measurement scores (see Table 1). Children from the experimental group took part in the "ToM program for children" while the control group benefited from the same program after post-test. This post-test session took place after implementing the 8 sessions with children in the experimental group and included all of the measures, except for the Wechsler preschool and primary scales and the Child Behavior Checklist. 
Table 1. Demographic and individual characteristics: Mean scores and standard deviations for each group in pre-test and between-group comparisons

\begin{tabular}{|c|c|c|c|c|}
\hline & & $\begin{array}{l}\text { Control group } \\
(n=15)\end{array}$ & $\begin{array}{l}\text { Experimental group } \\
(n=15)\end{array}$ & \\
\hline \multicolumn{2}{|l|}{ Variables } & $M(\mathrm{SD})$ & $M(\mathrm{SD})$ & $X^{2 /} t$ \\
\hline \multicolumn{2}{|l|}{ Sex (\% boys) } & $86 \%$ & $66 \%$ & 1.68 \\
\hline \multicolumn{2}{|l|}{ CA (in months) } & $109.6(12.51)$ & $104.13(25.37)$ & .75 \\
\hline \multicolumn{2}{|l|}{ GDA } & $63.47(16.18)$ & $61.67(12.57)$ & .34 \\
\hline \multicolumn{2}{|l|}{ VDA } & $62.1(15.85)$ & $60.77(13.27)$ & .25 \\
\hline \multirow[t]{3}{*}{ Family measures } & Family income & $3.20(1.15)$ & $3.64(.81)$ & .71 \\
\hline & Mothers' education $(\max =7)$ & $2.45(1.44)$ & $2.63(1.6)$ & -.24 \\
\hline & Fathers' education $(\max =7)$ & $3.33(1.22)$ & $3.83(1.6)$ & -.65 \\
\hline \multirow[t]{8}{*}{$\begin{array}{l}\text { Explicit ToM } \\
\text { measures }\end{array}$} & $\begin{array}{l}\text { ToM Task Battery total }(\max = \\
15)\end{array}$ & $8.07(2.52)$ & $8.33(3.15)$ & -.26 \\
\hline & Affective ToM Task Battery & $4.8(1.15)$ & $4.93(1.38)$ & -.27 \\
\hline & Cognitive ToM Task Battery & $2.64(1.15)$ & $2.86(1.46)$ & -.43 \\
\hline & Mixed ToM Task Battery & $.92(.95)$ & $.64(1.08)$ & .71 \\
\hline & ToM emotions $(\max =12)$ & $6.9(1.63)$ & $7.33(2.77)$ & -.52 \\
\hline & ToM emotions - causes $(\max =6)$ & $3.87(.85)$ & $4.3(1.88)$ & -1.13 \\
\hline & $\begin{array}{l}\text { ToM emotions }- \text { consequences } \\
(\max =6)\end{array}$ & $3.5(1.59)$ & $4.23(1.93)$ & -.81 \\
\hline & ToM beliefs $(\max =5)$ & $2.53(1.26)$ & $3.13(1.42)$ & -1.22 \\
\hline \multirow{4}{*}{$\begin{array}{l}\text { Applied ToM } \\
\text { measures }\end{array}$} & ToM Inventory $(\max =20)$ & $14.23(3.18)$ & $12.5(3.43)$ & 1.31 \\
\hline & ToM Inventory - Factor 1 & $13.03(4.56)$ & $10.88(3.65)$ & 1.3 \\
\hline & ToM Inventory - Factor 2 & $15.05(2.58)$ & $14.61(3.34)$ & .37 \\
\hline & ToM Inventory- Factor 3 & $15.86(2.45)$ & $13.65(4.7)$ & 1.49 \\
\hline \multirow{11}{*}{$\begin{array}{l}\text { Social } \\
\text { (mal)adjustment }\end{array}$} & EASE total & $59.07(18.66)$ & $57.38(19.35)$ & .23 \\
\hline & EASE ToM & $28.93(9.8)$ & $27.85(10.51)$ & .28 \\
\hline & EASE social skills & $30.14(9.44)$ & $29.38(9.17)$ & .21 \\
\hline & Externalizing problems & $65(13.58)$ & $75.05(18.25)$ & -1.65 \\
\hline & Internalizing problems & $73.36(18.08)$ & $74.78(11.27)$ & -.25 \\
\hline & Social competences & $106(23.48)$ & $118.87(29.95)$ & -1.27 \\
\hline & General adjustment & $244.36(40.49)$ & $268.71(48.76)$ & -1.44 \\
\hline & CBCL EB & $16.47(10.44)$ & $19.25(11.91)$ & -.65 \\
\hline & CBCL IB & $17.53(9.03)$ & $18.42(10.04)$ & -.24 \\
\hline & Emotion Regulation & $3.01(.33)$ & $2.91(.4)$ & .71 \\
\hline & Emotion Dysregulation & $2.01(.35)$ & $1.99(.52)$ & .1 \\
\hline
\end{tabular}

Note. $\mathrm{CA}=$ Chronological Age; GDA = Global Developmental Age; IQ = Intellectual Quotient; CBCL = Child Behavior Checklist; EB = Externalizing Behavior; IB = Internalizing Behavior; EASE = Social Adjustment Scale for Children

2.3.1 ToM Program for Children (Jacobs \& Nader-Grosbois, 2018)

The ToM program for children consisted of eight 45-minute sessions that took place two times a week and were implemented in groups of three children with IDs by two trainers. The program is modeled after a literature review and the program of Howlin et al. (2011) that described developmental stages of acquisition. For example, the understanding of belief is trained before that of false belief and emotional facial expression is trained first on photographs and then on schematic faces. The sessions' complexity increased over time, considering each child's zone of proximal development. The program was aimed at fostering comprehension of the nine mental states described by Flavell (1999). Each session focused either on affective or cognitive mental states. It was only during the seventh session that trainers began discussing the link between emotion, desire and belief. Materials such as games, videos, pictorial books were chosen considering 
which mental states each elicits (see Appendix B). Sessions started with a reminder, then trainers implemented 3-4 activities and closed the session by reading a pictorial book. Techniques used throughout sessions matched both general and specific objectives (see Appendix C). For example, the experimenter asked questions related to affective or cognitive mental states and explained the correct answer using key concepts (e.g., "You feel happiness when something pleasant occurs or when you received a present"). Repetition of these key questions and concepts fostered a cognitive routine that ensures generalization of knowledge. Similarly, knowing the key role of language and conversations in ToM abilities' development (Vygotsky, 1978), it was essential to support discussions between trainers and peers, and between peers themselves. In fact, children helped each other to find the correct answer, gave alternative justifications or interpretations which emphasized the possibility to share diverse perspectives on the same situations. The selection of these techniques was based on proof of their potential effectiveness in young children with developmental disorders.

\section{Results}

\subsection{Training Effects on Theory of Mind Abilities}

To evaluate training effect, we firstly used t tests to compare means and identified time effect. Secondly, we look for group by time interaction using repeated measure ANOVAS. As can be seen in Table 2, the control group did not significantly improve in their cognitive or affective ToM skills at the post-test, whereas the experimental group's ToM abilities improved after training. Compared with the pre-test, significant improvements were observed on ToM abilities, notably on the total ToM Task Battery $(t=-3.97 ; p=.001 ; d=1.02)$. Nevertheless, improvements differ considering affective or cognitive ToM.

Regarding affective ToM, children of the experimental group improve their performance in the affective score $(t=-2.28$; $p \leq .05 ; d=.60)$ of ToM Task Battery and in ToM-emotions $(t=-2.61 ; p \leq .05 ; d=.58)$, in comparison with the pretest. Concerning ToM-emotions, repeated measures ANOVAs show group by time interaction effects, but only for the subscale evaluating the comprehension of consequences of emotions $\left(F=5.58 ; p \leq .05 ; \eta^{2}=.17\right)$.

Concerning cognitive ToM, improvements noticed are greater. Compared with the pre-test, children of the experimental group improve their abilities in the cognitive score $(t=-3.55 ; p \leq .01 ; d=1.17)$ of ToM task battery and in ToM-beliefs $(t=-5.05 ; p=.000 ; d=1.33)$. Repeated measures ANOVAs show significant interaction effects group by time for the cognitive score of ToM task Battery $\left(F=4.26 ; p \leq .05 ; \eta^{2}=.15\right)$ and for the ToM-beliefs task $\left(F=13.41 ; p \leq .001 ; \eta^{2}\right.$ $=.32$ ). Simultaneously, a significant interaction effect group by time is obtained for the score corresponding with the third factor of the ToMI $\left(F=6.9 ; p \leq .05 ; \eta^{2}=.33\right)$. Parents perceived a significant improvement of the comprehension of cognitive mental states in their children. Moreover, thanks to a One-way ANOVA, we compare children that display better ToM abilities at post-test to those improving moderately and to the control group. Results show that children which improve the most, are those which display a lower level of understanding of cognitive mental states, at the pretest $(F=$ $\left.5.79 ; p=.009 ; \eta^{2}=.43\right)$. 
Table 2. Within and between group comparisons: Means and standard deviations on pre-test and post-test in ToM, emotion regulation and social adjustment measures

\begin{tabular}{|c|c|c|c|c|c|c|c|c|c|}
\hline \multirow[b]{3}{*}{ Variables } & & \multicolumn{3}{|c|}{ Control group } & \multicolumn{3}{|c|}{ Experimental group } & \multirow[b]{2}{*}{$\begin{array}{c}\text { Analysis } \\
(F)\end{array}$} & \multirow[b]{3}{*}{$\begin{array}{c}\text { Partial } \\
\text { Eta }^{2}\end{array}$} \\
\hline & & Pre-test & Post-test & $\triangle$ & Pre-test & Post-test & $\triangle$ & & \\
\hline & & $M(\mathrm{SD})$ & $M(\mathrm{SD})$ & $t$ & $M(\mathrm{SD})$ & $M(\mathrm{SD})$ & $t$ & $\begin{array}{l}\text { Group by } \\
\text { time } \\
\text { interaction }\end{array}$ & \\
\hline Explicit & ToM Task & & & & & & & & \\
\hline \multirow[t]{8}{*}{$\begin{array}{l}\text { ToM } \\
\text { measures }\end{array}$} & $\begin{array}{l}\text { Battery total } \\
(\max =15)\end{array}$ & $8.07(2.52)$ & $7.87(2.33)$ & .37 & $8.33(3.15)$ & $11.2(2.4)$ & $-3.97 * * *$ & $11.47 * *$ & .29 \\
\hline & $\begin{array}{l}\text { Affective ToM } \\
\text { Task Battery } \\
(\max =6)\end{array}$ & $4.8(1.15)$ & $4.8(1.21)$ & .00 & $4.93(1.38)$ & $5.62(.87)$ & $-2.28 *$ & 3.24 & \\
\hline & $\begin{array}{l}\text { Cognitive ToM } \\
\text { Task Battery } \\
(\max =6)\end{array}$ & $2.64(1.15)$ & $2.87(1.64)$ & -.67 & $2.86(1.46)$ & $4.3(.95)$ & $-3.55^{* *}$ & $4.26^{*}$ & .15 \\
\hline & $\begin{array}{l}\text { Mixed ToM Task } \\
\text { Battery }(\max =3)\end{array}$ & $.92(.95)$ & $.33(.62)$ & 1.67 & $.64(1.08)$ & $1.42(1.38)$ & $-2.42 *$ & $8.2 * *$ & .26 \\
\hline & $\begin{array}{l}\text { ToM emotions } \\
(\max =12)\end{array}$ & $6.9(1.63)$ & $6.5(1.36)$ & 1.03 & $7.33(2.77)$ & $8.93(2.76)$ & $-2.61 *$ & $7.82 * *$ & .22 \\
\hline & $\begin{array}{l}\text { ToM emotions }- \\
\text { causes }(\max =6)\end{array}$ & $3.87(.85)$ & $3.90(1.27)$ & -.13 & $4.3(1.88)$ & $5.18(1.96)$ & -1.87 & 2.69 & \\
\hline & $\begin{array}{l}\text { ToM emotions - } \\
\text { consequences } \\
(\max =6)\end{array}$ & $3.5(1.59)$ & $3.57(1.73)$ & -.16 & $4.23(1.93)$ & $5.82(2.62)$ & $-3.29 * *$ & $5.58^{*}$ & .17 \\
\hline & $\begin{array}{l}\text { ToM beliefs } \\
(\max =5)\end{array}$ & $2.53(1.26)$ & $2.73(.99)$ & -1.06 & $3.13(1.42)$ & $4.6(.66)$ & $-5.05 * * * *$ & $13.41 * * *$ & .32 \\
\hline \multirow{4}{*}{$\begin{array}{l}\text { Applied } \\
\text { ToM } \\
\text { measures }\end{array}$} & $\begin{array}{l}\text { ToM Inventory } \\
(\max =20)\end{array}$ & $14.23(3.18)$ & $13.78(7.31)$ & .11 & $12.5(3.43)$ & $14.57(4.15)$ & -1.35 & .79 & \\
\hline & $\begin{array}{l}\text { ToM Inventory - } \\
\text { Factor } 1\end{array}$ & $13.03(4.56)$ & $12.91(11.07)$ & -.05 & $10.88(3.65)$ & $13.06(5.61)$ & -.91 & .23 & \\
\hline & $\begin{array}{l}\text { ToM Inventory - } \\
\text { Factor } 2\end{array}$ & $15.05(2.58)$ & $15.55(5.31)$ & -.51 & $14.61(3.34)$ & $15.86(2.81)$ & -.96 & .04 & \\
\hline & $\begin{array}{l}\text { ToM Inventory- } \\
\text { Factor } 3\end{array}$ & $15.86(2.45)$ & $13.28(4.49)$ & $2.21^{\mathrm{a}}$ & $13.65(4.7)$ & $16.03(3.75)$ & -1.54 & $6.9^{*}$ & .33 \\
\hline
\end{tabular}

Note. $\triangle=$ post-test $/$ pre-test difference. ToM $=$ Theory of Mind; ${ }^{*} \mathrm{p} \leq .05,{ }^{*} \mathrm{p} \leq .01,{ }^{*} * * \mathrm{p} \leq .001, * * * * p=.000,{ }^{\mathrm{a}}$ $=p=.055$.

\subsection{Training Effects on Social (mal)Adjustment}

As can be seen in Table 3, parents estimated that neither children in the experimental group nor children in the control group had better social adjustment skills at the post-test. Nevertheless, teachers evaluated children in the experimental group as displaying better abilities in social adjustment after the ToM program for children. According to a repeated measures ANOVA, a significant group $\mathrm{x}$ time effect was found for scores in EASE completed by teachers $(F=7.9 ; p$ $\left.=.01 ; \eta^{2}=.27\right)$. The improvement was assessed by teachers as greater for items relating to the use of ToM abilities $(F=$ $\left.8.78 ; p=.007 ; \eta^{2}=.29\right)$ than of social skills $\left(F=4.8 ; p=.04 ; \eta^{2}=.19\right)$. 
Table 3. Within and between group comparisons: Means and standard deviations on pre-test and post-test in social adjustment and emotion regulation measures

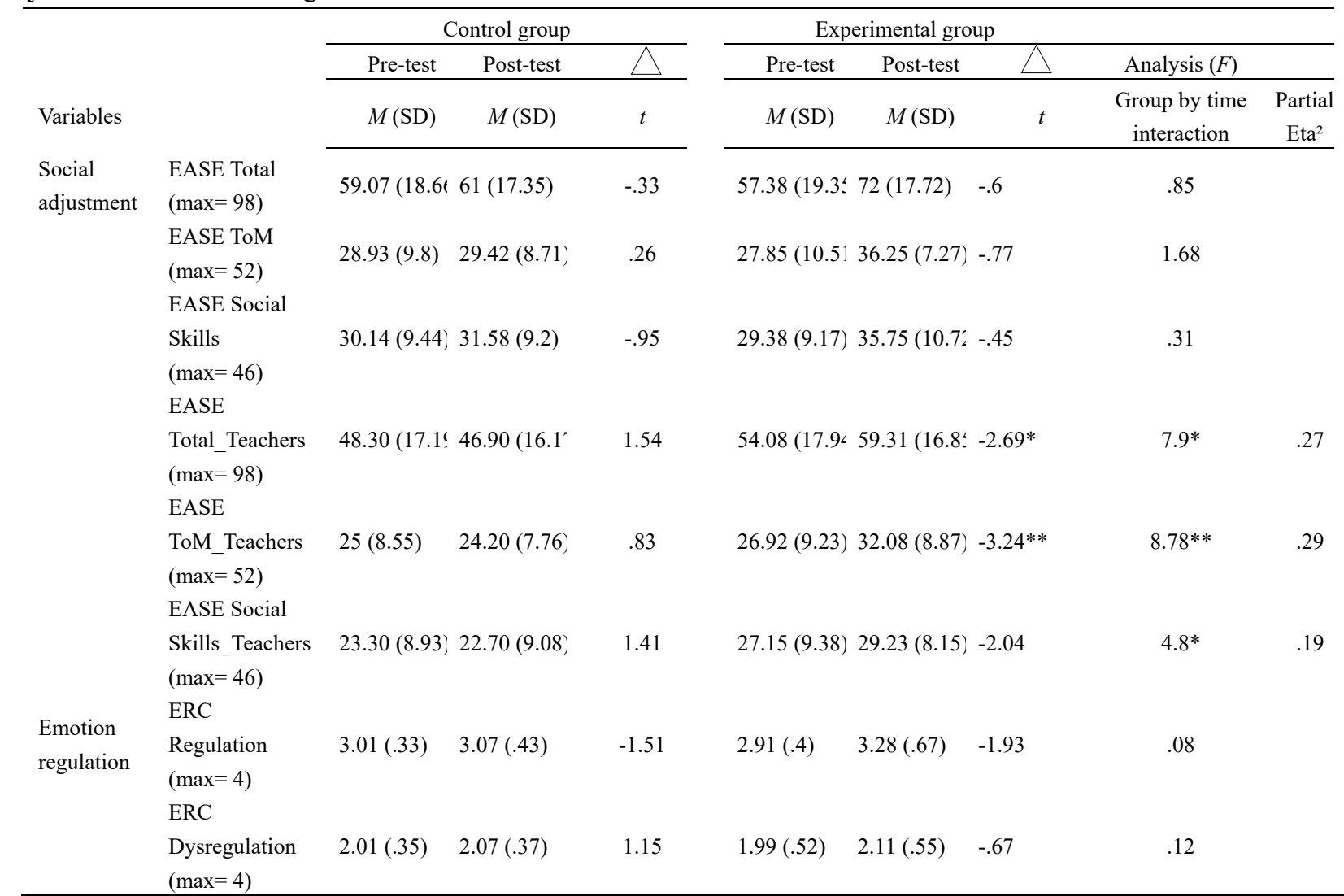

Note. $\triangle=$ post-test $/$ pre-test difference. ToM $=$ Theory of Mind; ERC $=$ Emotion Regulation Checklist; EASE $=$ Social Adjustment Scales; $* \mathrm{p} \leq .05, * * \mathrm{p} \leq .01, * * * \mathrm{p} \leq .001, * * * * p=.000,{ }^{\mathrm{a}}=p=.055$.

The results concerning social competences and behavior were different according to context. Parents noticed no improvement in children, whereas teachers evaluated children in the experimental group as displaying less externalizing and internalizing behavior after the training sessions. A repeated measures ANOVA showed a significant group by time interaction effect in scores on the CBCL measure for externalizing $\left(F=14.15 ; p=.001 ; \eta^{2}=.37\right)$ and internalizing $(F=$ $12.69 ; p=.002 ; \eta^{2}=.35$ ) behavior (see Table 2 ). After the ToM program for children, children were not perceived by their parents as better at regulating their emotions (see Table 2).

\section{Discussion}

The present study aimed to test the effectiveness of a new "ToM program for children" among children with IDs. Its unique contribution is that it considers affective and cognitive mental states and is in line with the strengths and impairments of children with IDs. We looked at the performance in ToM, social adjustment and emotion regulation of children who participants in this program in comparison to a control group. Results showed that this program fosters ToM abilities and social adjustment. Nevertheless, positive effects varied depending on affective or cognitive mental states.

As demonstrated by other studies (e.g. Jacobs et al., 2016; Lachavanne \& Barisnikov, 2013; Stewart \& Singh, 1995), an adapted training focusing on affective ToM supports the understanding of desires and emotions (notably the causes of emotions) despite the inter- and intra-variability among children. In fact, some children in the present sample displayed different levels of intensity and progression, which influences the improvement of ToM abilities in various ways. Additionally, enhancements in emotion abilities were seen primarily in the comprehension of consequences of emotions. This ability is acquired at approximately 6 years old (Wellman \& Liu, 2004; Westby \& Robinson, 2014). Yet, some children in the present sample presented a GDA of 5 and had already acquired the understanding of desire and causes of emotions. Therefore, they were more likely to acquire the comprehension of consequences of emotions, by training understanding of affective mental states. This result reflects that one of factors explaining the effectiveness of this program corresponds to respecting the zone of proximal development (Vygotsky, 1978) of each subgroup of children. The most significant results concerned cognitive ToM. After training, the experimental group showed a better comprehension of cognitive mental states, such as belief or perspective taking, than the control group. Moreover, children with low cognitive 
ToM benefited the most from the ToM program for children. This could be explained by the fact that children with IDs display deficits in the understanding of cognitive mental states (Barisnikov et al., 2002; Fiasse \& Nader-Grosbois, 2012; Thirion-Marissiaux \& Nader-Grosbois, 2008a) while affective ToM is delayed (Baurain \& Nader-Grosbois, 2012; NaderGrosbois, Houssa, \& Mazzone, 2013; Thirion-Marissiaux \& Nader-Grosbois, 2008c). A lot of studies attest to the effectiveness of training focusing on cognitive ToM, particularly for beliefs comprehension. For example, "Thought bubbles" training has been proven effective with children with autistic spectrum disorder and IDs (Paynter \& Peterson, 2013; Wellman et al., 2002). Nevertheless, the present study indicates that it is possible to support the comprehension of other cognitive mental states, beyond beliefs. This learning seemed to generalize to diverse contexts and particularly at home. Parents perceived that their child used better their understanding of beliefs and intentions in daily life, after participating in our program.

Given the results for social adjustment and emotion regulation, it is possible to better understand the causal contribution of ToM abilities on these social skills. Nevertheless, these effects were noticed only in a school setting. Teachers perceived children with IDs as more socially adjusted after the program, suggesting that these children were more polite, disciplined and responsive to others in a social situation with peers. This finding is in line with those of Nader-Grosbois et al. (2013) suggesting that children with IDs who are more tolerant, prosocial and integrated display a better understanding of emotion. Parents did not identify similar improvements suggesting that generalization occurs only at school or that parents did not have the opportunity to observe their child in diverse social interactions with multiple partners. Parents perceived no significant effect in terms of emotion regulation. It could be explained by the fact that although the emotion regulation checklist was completed by parents while, as with social adjustment skills, emotion regulation may be observed more easily at school. Furthermore, Thirion-Marissiaux and Nader-Grosbois (2008c) highlighted that parents may underestimate social abilities in their children with IDs because they refer to their child's chronological age rather to their developmental age. Although ToM competencies relate to emotion regulation when it is assessed in observational studies with children with IDs (Baurain \& Nader-Grosbois, 2013), children with IDs have greater difficulty handling situations where emotions are aroused (Baurain \& Nader-Grosbois, 2013), which could limit the effectiveness of the ToM training. Other deficient factors such as social information processing (Jacobs \& Nader-Grosbois, Submitted) or executive function (e.g., inhibition; (Gligorović \& Buha, 2012) should be supported in addition to the present training in order to reinforce emotion regulation in children with IDs.

Some limitations have to be considered. Statistical power was limited due to the quite small sample size. Recruitment was limited by strict inclusion criteria and the necessity to obtain consent from all participating children, parents, and teachers. Two children missed one session and after their absence, they participated in a 10-minute feedback session focusing on what had been done during the missed session. An additional measure of language or executive functions might have been useful, as language (Hippolyte, Iglesias, Van der Linden, \& Barisnikov, 2010; Lohmann \& Tomasello, 2003; Westby \& Robinson, 2014) and executive functions, most notably working memory (Dennis, Agostino, Roncadin, \& Levin, 2009; Lecce \& Bianco, 2018) and inhibition (Josef Perner, Lang, \& Kloo, 2002), could be underlying mechanisms of ToM development. In the future, it would be interesting to implement the ToM program for children along with an executive function training, such as inhibition training. It could reinforce children's control of socially adjusted behavior and emotion regulation skills. Another limitation is that the children did not take part in a follow-up session.

To conclude, the ToM program for children seems effective with children with IDs. The material and techniques of the present program can be seen as adaptive since it respects objective and specific affective and cognitive ToM profiles of these children. Despite verbal difficulties, techniques of discussion and feedback seemed beneficial for children with IDs, just as they are for typically developing children (Gola, 2012; Lecce, Bianco, Devine, Hughes, \& Banerjee, 2014). Considering the developmental period and the nature of difficulties, namely those stemming from the deficit or delay hypothesis, in children with IDs has crucial consequences for professionals and families (Reilly, 2012). The present study suggests that the preliminary analysis of the affective and cognitive ToM profile is a necessary first step of intervention. According to a qualitative observation, the group training design allows for socio-cognitive debate between children, which contributes to the effectiveness of our program. But, in an individual setting, implementation of ToM program for children is possible - considering the child's socio-emotional profile. Current results emphasized the importance of parents' involvement in the intervention process in order to generalize learning to the everyday context. Generalization could be reinforced by homework based on the materials and techniques used by the professional trainers, but adapted to a home setting. Parents could also benefit from support concerning their emotion socialization behavior, since parental impact on ToM abilities and emotion regulation skills is well-known (Jacobs, Mazzone, Simon, \& Nader-Grosbois, 2019). Other actors of prevention, change and learning stability could be specialized teachers. They could implement activities inspired by ToM programs for children in their classroom. Beyond its effectiveness in this experimental study, our adapted training for children with IDs, the ToM program for children, highlights guidelines for professionals, parents and teachers to foster both affective and cognitive ToM in order to prevent social maladjustment and encourage social inclusion. 


\section{Acknowledgements}

The authors would like to thank the children, parents and teachers for their participation in this study. We are also grateful to the Marguerite-Marie Delacroix Foundation for its financial support, as well as the Baron Frère Chair in special education. We are finally thankful to Poline Simon for collecting data. We finally would like to thank Christa Taylor for her proofreading.

\section{References}

AAIDD. (2011). Deficience intellectuelle. Definition, classification et systemes de soutien. Paper presented at the Consortium national de recherche sur l'integration sociale, Trois-Rivieres, Canada.

Achenbach, T. M. (1991). Manual for the child behavior checklist/4-18 and 1991 Profile.

Astington, J. W. (2003). Sometimes necessary, never sufficient: Falsebelief understanding and social competence. In B. Repacholi \& V. Slaughter (Eds.). Individual differences in theory of mind: Implications for typical and atypical development (pp. 13-38). New York: Psychology Press.

Baglio, G., Blasi, V., Sangiuliano Intra, F., Castelli, I., Massaro, D., Baglio, F., \& Marchetti, A. (2016). Social competence in children with borderline intellectual functioning: delayed development of theory of mind across all complexity levels. Frontiers in psychology, 7, 1604. https://doi.org/10.3389/fpsyg.2016.01604

Barisnikov, K., Van der Linden, M., \& Detraux, J. J. (2002). Cognition sociale, troubles du comportement social et émotionnel chez les personnes présentant une déficience mentale. In G. Petitpierre (Ed.). Enrichir les compétences (pp. 31 - 39). Lucerne: Edition SPC.

Barthélémy, A., \& Tartas, V. J. E. (2009). Faire-semblant et tromperie tactique: une étude développementale. Enfance (4), 383-395. https://doi.org/10.4074/S0013754509004029

Baurain, C., \& Nader-Grosbois, N. (2012). Socio-emotional regulation in children with intellectual disability and typically developing children in interactive contexts. ALTER-European Journal of Disability Research, 6(2), 75-93. https://doi.org/10.1016/j.alter.2012.02.001

Baurain, C., \& Nader-Grosbois, N. (2013). Theory of Mind, Socio-Emotional Problem-Solving, Socio-Emotional Regulation in Children with Intellectual Disability and in Typically Developing Children. Journal of Autism and Developmental Disorders, 43(5), 1080-1097. https://doi.org/10.1007/s10803-012-1651-4

Charman, T., \& Campbell, A. (2002). Theory of mind and social competence in individuals with a mental handicap. Journal of Developmental and Physical Disabilities, 14(3), 263-276. https://doi.org/10.1023/A:1016076405731

Charman, T., Baron-Cohen, S., Swettenham, J., Baird, G., Cox, A., \& Drew, A. (2000). Testing joint attention, imitation, and play as infancy precursors to language and theory of mind. Cognitive Development, 15(4), 481-498. https://doi.org/10.1016/S0885-2014(01)00037-5

Dekker, M. C., \& Koot, H. M. (2003). DSM-IV disorders in children with borderline to moderate intellectual disability. I: Prevalence and impact. Journal of the American Academy of Child \& Adolescent Psychiatry, 42(8), 915-922. https://doi.org/10.1097/01.CHI.0000046892.27264.1A

Deneault, J., \& Ricard, M. (2013). Are emotion and mind understanding differently linked to young children's social adjustment? Relationships between behavioral consequences of emotions, false belief, and SCBE. The Journal of genetic psychology, 174(1), 88-116. https://doi.org/10.1080/00221325.2011.642028

Denham, S. A., Blair, K. A., DeMulder, E., Levitas, J., Sawyer, K., Auerbach-Major, S., \& Queenan, P. (2003). Preschool emotional competence: Pathway to social competence? Child Development, 74(1), 238-256. https://doi.org/10.1111/1467-8624.00533

Dennis, M., Agostino, A., Roncadin, C., \& Levin, H. (2009). Theory of mind depends on domain-general executive functions of working memory and cognitive inhibition in children with traumatic brain injury. Journal of Clinical Experimental Neuropsychology, 31(7), 835-847. https://doi.org/10.1080/13803390802572419

Fiasse, C., \& Nader-Grosbois, N. (2012). Perceived social acceptance, theory of mind and social adjustment in children with intellectual disabilities. Research in Develomental Disabilities, 33(6), 1871-1880. https://doi.org/10.1016/j.ridd.2012.05.017

Flavell, J. H. (1986). The development of children's knowledge about the appearance-reality distinction. American Psychologist, 41(4), 418-425.https://doi.org/10.1037/0003-066X.41.4.418

Flavell, J. H. (1999). Cognitive development: Children's knowledge about the mind. Annual review of psychology, 50(1), 21-45. https://doi.org/10.1146/annurev.psych.50.1.21 
Flavell, J. H., Everett, B. A., Croft, K., \& Flavell, E. R. (1981). Young children's knowledge about visual perception: Further evidence for the level 1-level 2 distinctions. Developmental Psychology, 17(1), 99-103. https://doi.org/10.1037/0012-1649.17.1.99

Garitte, C. (2003). La reconnaissance des expressions faciales chez des enfants de 8 ans d'âge réel et/ou mental: processus cognitifs ou sociaux?: Les troubles du comportement en milieu scolaire. Approche neuropsychologique des apprentissages chez l'enfant, (71), 48-52.

Gevers, C., Clifford, P., Mager, M., \& Boer, F. (2006). Brief report: A theory-of-mind-based social-cognition training program for school-aged children with pervasive developmental disorders: An open study of its effectiveness. Journal of Autism and Developmental Disorders, 36(4), 567-571. https://doi.org/10.1007/s10803-006-0095-0

Giaouri, S., Alevriadou, A., \& Tsakiridou, E. (2010). Theory of mind abilities in children with Down syndrome and nonspecific intellectual disabilities: An empirical study with some educational implications. Procedia-Social and Behavioral Sciences, 2(2), 3883-3887. https://doi.org/10.1016/j.sbspro.2010.03.609

Gligorović, M., \& Buha, N. (2012). Inhibitory control as a factor of adaptive functioning of children with mild intellectual disability. Specijalna edukacija i rehabilitacija, 11(3), 403-417. https://doi.org/10.5937/specedreh11-2503

Gola, A. A. H. (2012). Mental verb input for promoting children's theory of mind: A training study. Cognitive Development, 27(1), 64-76. https://doi.org/10.1016/j.cogdev.2011.10.003

Hadwin, J., Baron-Cohen, S., Howlin, P., \& Hill, K. (1996). Can we teach children with autism to understand emotions, belief, or pretence? Development and psychopathology, 8(02), 345-365. https://doi.org/10.1017/S0954579400007136

Hippolyte, L., Iglesias, K., Van der Linden, M., \& Barisnikov, K. (2010). Social reasoning skills in adults with Down syndrome: the role of language, executive functions and socio-emotional behaviour. Journal of Intellectual Disability Research, 54(8), 714-726. https://doi.org/10.1111/j.1365-2788.2010.01299.x

Hofmann, S. G., Doan, S. N., Sprung, M., Wilson, A., Ebesutani, C., Andrews, L. A., \& Harris, P. L. (2016). Training children's theory-of-mind: A meta-analysis of controlled studies. Cognition, 150, 200-212. https://doi.org/10.1016/j.cognition.2016.01.006

Houssa, M., \& Nader-Grosbois, N. (2016). Could Social Cognition Training Reduce Externalizing Behaviors and Social Maladjustment in Preschoolers. Journal of Psychological Abnormalities, S1(5), 10. https://doi.org/10.4172/24719900.S1-005

Houssa, M., Jacobs, E., \& Nader-Grosbois, N. (2016). Impact of short-term training in social cognition in preschoolers with externalizing behavior. Journal of Education and Training Studies, 5(1), 110-123. https://doi.org/10.11114/jets.v5i1.2081

Houssa, M., Mazzone, S., \& Nader-Grosbois, N. (2014). Validation d'une version francophone de l'inventaire de la Théorie de l'Esprit (ToMI-vf). Revue Européenne de Psychologie Appliquée/European Review of Applied Psychology, 64(4), 169-179. https://doi.org/10.1016/j.erap.2014.02.002

Howlin, P., Baron-Cohen, S., \& Hadwin, J. (2011). Apprendre aux enfants autistes à comprendre la pensée des autres. Bruxelles: de Boeck.

Hughes, C., Soares-Boucaud, I., Hochmann, J., \& Frith, U. (1997). Social behaviour in pervasive developmental disorders: Effects of informant, group and "theory-of-mind". European child \& adolescent psychiatry, 6(4), 191-198. https://doi.org/10.1007/BF00539925

Hutchins, T. L., Bonazinga, L. A., Prelock, P. A., \& Taylor, R. S. (2008). Beyond false beliefs: The development and psychometric evaluation of the Perceptions of Children's Theory of Mind Measure-Experimental Version (PCToMM-E). Journal of Autism and Developmental Disorders, 38(1), 143-155. https://doi.org/10.1007/s10803007-0377-1

Hutchins, T. L., Prelock, P. A., \& Bonazinga, L. (2012). Psychometric evaluation of the Theory of Mind Inventory (ToMI): A study of typically developing children and children with autism spectrum disorder. Journal of Autism and Developmental Disorders, 42(3), 327-341. https://doi.org/10.1007/s10803-011-1244-7

Hynes, C. A., Baird, A. A., \& Grafton, S. T. (2006). Differential role of the orbital frontal lobe in emotional versus cognitive perspective-taking. $\quad$ Neuropsychologia, 374-383. https://doi.org/10.1016/j.neuropsychologia.2005.06.011

Jacobs, E., \& Nader-Grosbois, N. (2018). ToM Program for Children. UCLouvain. Louvain-La-Neuve. 
Jacobs, E., \& Nader-Grosbois, N. (Submitted). Social information processing: a key to supporting emotion regulation and social behaviors in children with intellectual disabilities? Journal of Education and Training Studies.

Jacobs, E., Léonard, C., Nader-Grosbois, N., Houssa, M., \& Mazzone, S. (2016). Entrainer la cognition sociale auprès d'enfants présentant une déficience intellectuelle. Revue francophone de la déficience intellectuelle, 27, 127-140. https://doi.org/10.7202/1043129ar

Jacobs, E., Mazzone, S., Simon, P., \& Nader-Grosbois, N. (2019). The Unexpected Impact of Parental Emotional Socialization on Theory of Mind and Emotion Regulation: The Case of Children with Intellectual Disabilities. Psychology, 10, 1302-1332. https://doi.org/10.4236/psych.2019.109084

Lachavanne, A., \& Barisnikov, K. (2013). Rééducation des compétences socio-émotionnelles pour des adultes présentant une déficience intellectuelle. Revue Européenne de Psychologie Appliquée/European Review of Applied Psychology, 63(6), 345-352. https://doi.org/10.1016/j.erap.2013.09.002

Lecce, S., \& Bianco, F. (2018). Working memory predicts changes in children's theory of mind during middle childhood: A training study. Cognitive Development, 47, 71-81. https://doi.org/10.1016/j.cogdev.2018.04.002

Lecce, S., Bianco, F., Devine, R. T., Hughes, C., \& Banerjee, R. (2014). Promoting theory of mind during middle childhood: A training program. Journal of Experimental Child Psychology, 126, 52-67. https://doi.org/10.1016/j.jecp.2014.03.002

Leffert, J. S., \& Siperstein, G. N. (2002). Social cognition: A key to understanding adaptive behavior in individuals with mild mental retardation. International Review of Research in Mental Retardation, 25, 135-181. https://doi.org/10.1016/S0074-7750(02)80008-8

Lohmann, H., \& Tomasello, M. (2003). The role of language in the development of false belief understanding: A training study. Child Development, 74(4), 1130-1144. https://doi.org/10.1111/1467-8624.00597

McGregor, E., Whiten, A., \& Blackburn, P. (1998). Transfer of the picture-in-the-head analogy to natural contexts to aid false belief understanding in autism. Autism, 2(4), 367-387. https://doi.org/10.1177/1362361398024004

Meltzoff, A. N. (2002). Imitation as a mechanism of social cognition: Origins of empathy, theory of mind, and the representation of action. Blackwell handbook of childhood cognitive development, 6-25. https://doi.org/10.1002/9780470996652.ch1

Nader-Grosbois, N., \& Houssa, M. (2016). La Batterie de tâches de Théorie de l'esprit: Validation de la version francophone. Enfance, 2016(02), 141-166. https://doi.org/10.4074/S0013754516002019

Nader-Grosbois, N., \& Mazzone, S. (2015). Validation de la version francophone de l'Emotion Regulation Checklist (ERC-vf). Revue Européenne de Psychologie Appliquée, 65(1), 29-41. https://doi.org/10.1016/j.erap.2014.10.002

Nader-Grosbois, N., Houssa, M., \& Mazzone, S. (2013). How could Theory of Mind contribute the differentiation social adjustment profiles of children with externalizing behavior disorders and children with intellectual disabilities? Research in Develomental Disabilitites, 34(9), 2642-2660. https://doi.org/10.1016/j.ridd.2013.05.010

Oswald, D. P., \& Ollendick, T. H. (1989). Role taking and social competence in autism and mental retardation. Journal of autism and developmental disorders, 19(1), 119-127. https://doi.org/10.1007/BF02212723

Paynter, J., \& Peterson, C. C. (2013). Further evidence of benefits of thought-bubble training for theory of mind development in children with autism spectrum disorders. Research in Autism Spectrum Disorders, 7(2), 344-348. https://doi.org/10.1016/j.rasd.2012.10.001

Perner, J., Lang, B., \& Kloo, D. (2002). Theory of mind and self-control: More than a common problem of inhibition. Child development, 73(3), 752-767. https://doi.org/10.1111/1467-8624.00436

Perner, J., Leekam, H., \& Wimmer, H. (1987). Three-year-olds' difficulty with false belief: The case for a conceptual deficit. British Journal of Developmental Psychology, 5, 125-137. https://doi.org/10.1111/j.2044835X.1987.tb01048.x

Rakoczy, H. (2008). Taking fiction seriously: Young children understand the normative structure of joint pretence games. Developmental Psychology, 44(4), 1195-1201. https://doi.org/10.1037/0012-1649.44.4.1195

Ratcliffe, B., Wong, M., Dossetor, D., \& Hayes, S. (2014). Teaching social-emotional skills to school-aged children with Autism Spectrum Disorder: A treatment versus control trial in 41 mainstream schools. Research in Autism Spectrum Disorders, 8(12), 1722-1733. https://doi.org/10.1016/j.rasd.2014.09.010

Reilly, C. (2012). Behavioural phenotypes and special educational needs: is aetiology important in the classroom? Journal of Intellectual Disability Research, 56(10), 929-946. https://doi.org/10.1111/j.1365-2788.2012.01542.x 
Ricard, M., Cossette, L., \& Gouin Décarie, T. (1999). Développement social et affectif. In J. A. Ronda \& E. Esperet (Eds.), (pp. 215-231): Manuel de psychologie de l'enfant.

Serret, S., Hun, S., Iakimova, G., Lozada, J., Anastassova, M., Santos, A., \& Askenazy, F. (2014). Facing the challenge of teaching emotions to individuals with low- and high-functioning autism using a new Serious game: A pilot study. Molecular Autism, 5(1). https://doi.org/10.1186/2040-2392-5-37

Shamay-Tsoory, S. G., Shur, S., Barcai-Goodman, L., Medlovich, S., Harari, H., \& Levkovitz, Y. (2007). Dissociation of cognitive from affective components of theory of mind in schizophrenia. Psychiatry research, 149(1-3), 11-23. https://doi.org/10.1016/j.psychres.2005.10.018

Shields, A., \& Cicchetti, D. (1997). Emotion regulation among school-age children: The development and validation of a new criterion Q-sort scale. Developmental psychology, 33(6), 906-916. https://doi.org/10.1037/00121649.33.6.906

Shure, M. B. (1993). I can problem solve (ICPS): Interpersonal cognitive problem solving for young children. Early child development and care, 96(1), 49-64. https://doi.org/10.1080/0300443930960106

Stewart, C. A., \& Singh, N. N. (1995). Enhancing the recognition and production of facial expressions of emotion by children with mental retardation. Research in Develomental Disabilitites, 16(5), 365-382. https://doi.org/10.1016/0891-4222(95)00024-H

Swettenham, J. (1996). Can children with autism be taught to understand false belief using computers? Journal of Child Psychology and Psychiatry, 37(2), 157-165. https://doi.org/10.1111/j.1469-7610.1996.tb01387.x

Thirion-Marissiaux, A. F., \& Nader-Grosbois, N. (2008a). Theory of mind "beliefs", developmental characteristics and social understanding in children and adolescents with intellectual disabilities. Research in Develomental Disabilitites, 29(6), 547-566. https://doi.org/10.1016/j.ridd.2007.09.004

Thirion-Marissiaux, A. F., \& Nader-Grosbois, N. (2008b). Theory of Mind "emotion", developmental characteristics and social understanding in children and adolescents with intellectual disabilities. Research in Develomental Disabilitites, 29(5), 414-430. https://doi.org/10.1016/j.ridd.2007.07.001

Thirion-Marissiaux, A.-F., \& Nader-Grosbois, N. (2008c). Theory of mind and socio-affective abilities in disabled children and adolescents. European Journal of Disability Research, 2(2), 133-155. https://doi.org/10.1016/j.alter.2008.02.003

Tourrette, C., Recordon, S., Barbe, V., \& Soares-Boucaud, I. (2000). Attention conjointe préverbale et Théorie de l'esprit à 5 ans: la relation supposée entre ces deux capacités peut-elle être démontrée? Etude exploratoire chez des enfants non autistes. In G.-C. V. \& R. C. (Eds.), Autisme: perspectives actuelles (pp. 61-75). Paris: L'Harmattan.

Vygotsky, L. (1978). Interaction between learning and development. Readings on the development of children, 23(3), 3441.

Webster-Stratton, C., \& Hammond, M. (1997). Treating children with early-onset conduct problems: A comparison of child and parent training interventions. Journal of Consulting and Clinical Psychology, 65(1), 93-109. https://doi.org/10.1037/0022-006X.65.1.93

Wechsler, D. (2004). Echelle d'intelligence de Wechsler pour la période préscolaire et primaire, 3. Les éditions du Centre de Psychologie appliquée, Paris, France.

Wellman, H. M., \& Liu, D. (2004). Scaling of theory-of-mind tasks. Child Development, 75(2), 523-541. https://doi.org/10.1111/j.1467-8624.2004.00691.x

Wellman, H. M., Baron-Cohen, S., Caswell, R., Gomez, J. C., Swettenham, J., Toye, E., \& Lagattuta, K. (2002). Thoughtbubbles help children with autism acquire an alternative to a theory of mind. Autism, 6(4), 343-363. https://doi.org/10.1177/1362361302006004003

Westby, C., \& Robinson, L. (2014). A developmental perspective for promoting theory of mind. Topics in Language Disorders, 34(4), 362-382. https://doi.org/10.1097/TLD.0000000000000035

Williams, B. T., Gray, K. M., \& Tonge, B. J. (2012). Teaching emotion recognition skills to young children with autism: A randomised controlled trial of an emotion training programme. Journal of Child Psychology and Psychiatry and Allied Disciplines, 53(12), 1268-1276. https://doi.org/10.1111/j.1469-7610.2012.02593.x

Wimmer, H., \& Perner, J. (1983). Beliefs about beliefs: Representation and constraining function of wrong beliefs in young children's understanding of deception. Cognition, 13, 103-128. https://doi.org/10.1016/0010-0277(83)900045 
Appendix A. Table of ToM training studies in children with Intellectual Disabilities

\begin{tabular}{|c|c|c|c|c|}
\hline \multicolumn{2}{|l|}{ Authors } & $\begin{array}{l}\text { Stewart \& Singh } \\
\text { (1995) }\end{array}$ & $\begin{array}{l}\text { Lachavanne \& } \\
\text { Barisnikov (2013) }\end{array}$ & $\begin{array}{l}\text { Jacobs, Nader- } \\
\text { Grosbois, Houssa et al. } \\
\text { (2016) }\end{array}$ \\
\hline \multicolumn{2}{|l|}{ Sample } & $\begin{array}{l}\text { Children with IDs } \\
\text { (mild to moderate) } \\
(n=3) \\
\text { - IQ: } M=54 \\
\text { (between } 44 \text { to } 64) \\
\text { - CA: } M=12 \\
\text { (between } 12 \text { to } 13 \text { ) }\end{array}$ & $\begin{array}{l}\text { Adolescent with IDs } \\
\text { (mild to moderate) } \\
(n=17) \\
\text { - IQ: } M=60 \\
\text { - CA: } M=23 \text { (between } \\
18 \text { to } 42 \text { ) }\end{array}$ & $\begin{array}{l}\text { Children with IDs (mild } \\
\text { to moderate) } \\
(n=6) \\
\text { - CA: } M=9.5 \text { ( } 6 \text { to } 12) \\
\text { - DGA: } M=4.5\end{array}$ \\
\hline \multirow[t]{4}{*}{ Training } & Control group & & & $X(n=6)$ \\
\hline & Target & $\begin{array}{l}\text { - Emotions } \\
\text { (joy, anger, fear, } \\
\text { sadness, surprise, } \\
\text { disgust) }\end{array}$ & $\begin{array}{l}\text { - Emotions } \\
\text { - Social Problem Solving }\end{array}$ & $\begin{array}{l}\text { - Theory of Mind } \\
\text { - Social problem-solving }\end{array}$ \\
\hline & Timing sessions & $\begin{array}{l}-30 \text { sessions } \\
-8 \text { to } 12 \text { weeks } \\
\text { follow up }\end{array}$ & $\begin{array}{l}-9 \text { sessions }(90 \mathrm{~min}) \\
-1 \mathrm{x} / \text { week }\end{array}$ & - 1 session (45min.) \\
\hline & Individual or group? & Individual & Group (4 to 5) & Group (3) \\
\hline \multirow[t]{2}{*}{$\begin{array}{l}\text { Variables/ } \\
\text { Measures }\end{array}$} & Relating to ToM & $\begin{array}{l}\text { - Facial emotions } \\
\text { recognition (based } \\
\text { on FACS) }\end{array}$ & $\begin{array}{l}\text { - Emotions recognition } \\
\text { - Emotional attribution } \\
\text { task }\end{array}$ & $\begin{array}{l}\text { - Theory of Mind (ToM- } \\
\text { Emotions; ToM-Beliefs; } \\
\text { ToM Tasks Battery-vf) }\end{array}$ \\
\hline & $\begin{array}{l}\text { Relating to other } \\
\text { variables }\end{array}$ & & $\begin{array}{l}\text { - Social problem- } \\
\text { solving task } \\
\text { - Social behavior } \\
\text { (Development-al } \\
\text { Behavior Checklist) }\end{array}$ & $\begin{array}{l}\text { - Social adjustment } \\
\text { (EASE; SCBE) } \\
\text { - Social problem-solving } \\
\text { competence (RES) } \\
\text { - Emotion Regulation } \\
\text { (ERC-vf) }\end{array}$ \\
\hline Material & $\begin{array}{l}\text { Eliciting mental } \\
\text { states }\end{array}$ & $\begin{array}{l}\text { Photographs } \\
\text { (6/session) ; Stories; } \\
\text { Mirror }\end{array}$ & $\begin{array}{l}\text { Pictures; Photographs; } \\
\text { Stories; Mirror; } \\
\text { Interactive game; } \\
\text { Imitation; Discussions }\end{array}$ & $\begin{array}{l}\text { Pictures; Games; } \\
\text { Videos; Books }\end{array}$ \\
\hline \multirow[t]{4}{*}{ Techniques } & Repetition & $\mathrm{X}$ & & \\
\hline & Corrective feedback & $\mathrm{X}$ & $\mathrm{X}$ & $\mathrm{X}$ \\
\hline & Asking justification & & & $\mathrm{X}$ \\
\hline & $\begin{array}{l}\text { Link with child's } \\
\text { experience }\end{array}$ & & $\mathrm{X}$ & $\mathrm{X}$ \\
\hline \multirow[t]{2}{*}{ Results } & Effects on ToM & $\mathrm{X}$ & $\mathrm{X}$ & $\mathrm{X}$ \\
\hline & $\begin{array}{l}\text { Effects on other } \\
\text { variables }\end{array}$ & $\begin{array}{l}\text { (+ Facial emotion } \\
\text { expression } \\
\text { recognition })\end{array}$ & $\begin{array}{c}\mathrm{X} \\
\text { (- Behavior problems } \\
+ \text { Social Problem } \\
\text { Solving) }\end{array}$ & $\begin{array}{c}\mathrm{X} \\
\text { (Social problem solving) }\end{array}$ \\
\hline
\end{tabular}


Appendix B. Table of ToM training studies in children with Autistic Spectrum Disorder

\begin{tabular}{|c|c|c|c|c|c|}
\hline \multicolumn{2}{|l|}{ Authors } & $\begin{array}{l}\text { Wellman et al. } \\
(2002)\end{array}$ & $\begin{array}{l}\text { Williams, Gray, } \\
\text { Tonge (2012) }\end{array}$ & $\begin{array}{l}\text { Ratcliffe et al. } \\
(2014)\end{array}$ & $\begin{array}{l}\text { Serret et al } \\
(2014)\end{array}$ \\
\hline \multicolumn{2}{|l|}{ Sample } & $\begin{array}{l}\text { ASD Children \& } \\
\text { Adolescents } \\
\text { with/without IDs } \\
\text { (mild to } \\
\text { moderate) } \\
(n=7) \\
\text { - MA: } M=5.6 \\
\text { (between } 4 \text { to } 6.5 \text { ) } \\
\text { - CA: } M=11,2 \\
\text { (between } 8 \text { to } 18 \text { ) }\end{array}$ & $\begin{array}{l}\text { ASD Children } \\
\text { with/without IDs } \\
\text { (mild to moderate) } \\
\text { ( } n=28 \text { ) } \\
\text { - IQ: } M=76 \\
\text { (between } 42 \text { to } 107 \text { ) } \\
\text { - CA: } M=5 \\
\text { (between } 4.1 \text { to } 7.3 \text { ) }\end{array}$ & $\begin{array}{l}\text { ASD Children } \\
\text { without IDs } \\
(n=106) \\
\text { - CA: } M=9\end{array}$ & $\begin{array}{l}\text { ASD Children \& } \\
\text { Adolescents } \\
\text { with/without ID } \\
\text { (mild to } \\
\text { moderate) } \\
\text { ( } n=33 \text { ) } \\
\text { IQ: } M=70.5 \\
\text { (between } 35 \text { to } \\
\text { 129) } \\
\text { CA: } M=11.4 \\
\text { (between } 6 \text { to } 17 \text { ) }\end{array}$ \\
\hline \multirow[t]{4}{*}{ Training } & $\begin{array}{l}\text { Control } \\
\text { group }\end{array}$ & & $\mathrm{X}(n=27)$ & $\mathrm{X}(n=111)$ & \\
\hline & Target & - Beliefs & - Emotions & $\begin{array}{l}\text { - Emotion- Based } \\
\text { Social Skills Training } \\
\text { (EBSST) } \\
\text { - Emotional skills } \\
\text { - Emotional problem } \\
\text { solving } \\
\text { - ToM } \\
\text { - Emotion regulation } \\
\end{array}$ & - Emotions \\
\hline & $\begin{array}{l}\text { Timing } \\
\text { sessions }\end{array}$ & $\begin{array}{l}-6 \text { sessions }(30 \\
\text { min) } \\
-2 \text { to } 3 x \text { / week }\end{array}$ & $\begin{array}{l}\text { - } 15 \text { min. / day } \\
\text { - During } 1 \text { month } \\
\text { - Home } \\
-3 \text { months follow up }\end{array}$ & $\begin{array}{l}\text { - } 16 \text { sessions }(90 \mathrm{~min}) \\
-3 \mathrm{x} / \text { week } \\
\text { - During } 5 \text { weeks } \\
-6 \text { months follow up }\end{array}$ & $\begin{array}{l}\text { - } 8 \text { sessions } \\
-3 \text { x / week } \\
-1 \text { level / session }\end{array}$ \\
\hline & $\begin{array}{l}\text { Individual } \\
\text { or group? }\end{array}$ & Individual & Individual & Group of 3 to 8 & Individual \\
\hline \multirow[t]{2}{*}{$\begin{array}{l}\text { Variables/ } \\
\text { Measures }\end{array}$} & $\begin{array}{l}\text { Relating } \\
\text { to ToM }\end{array}$ & $\begin{array}{l}\text { - Cognitive ToM } \\
\text { ("Sally \& Anne" } \\
\text { \& "Smarties" } \\
\text { tasks) }\end{array}$ & $\begin{array}{l}\text { - Emotion } \\
\text { identification \& } \\
\text { matching tasks } \\
\text { (Based on FACS) } \\
\text { - Emotion recognition } \\
\text { \& ToM (NEPSY-II) } \\
\text { - Emotion \& desire } \\
\text { relating to ToM } \\
\text { (Mindreading task) }\end{array}$ & $\begin{array}{l}\text { - Emotional skills } \\
\text { (including ToM; } \\
\text { Emotions } \\
\text { Development } \\
\text { Questionnaire) }\end{array}$ & - Je StiMulE \\
\hline & $\begin{array}{l}\text { Relating } \\
\text { to other } \\
\text { variables }\end{array}$ & & $\begin{array}{l}\text { - QI (WPPSI-III) } \\
\text { - Social adjustment } \\
\text { (Vineland-II) } \\
\text { - ASD Diagnosis } \\
\text { (ADOS) }\end{array}$ & $\begin{array}{l}\text { - ASD Diagnosis } \\
\text { (SRS) } \\
\text { - Social skills (Social } \\
\text { Skills Improvement } \\
\text { System- Rating } \\
\text { Scale) } \\
\text { - Mental health } \\
\text { difficulties (Strengths } \\
\text { and Difficulties } \\
\text { Questionnaire) }\end{array}$ & \\
\hline
\end{tabular}


Appendix C. "ToM program for children" - Material

\begin{tabular}{|c|c|c|c|c|}
\hline \multirow{2}{*}{\multicolumn{2}{|c|}{ Material }} & \multicolumn{3}{|l|}{ Mental states } \\
\hline & & \multirow{2}{*}{ Emotions - expression } & \multirow{2}{*}{$\begin{array}{c}\text { Own } \\
\mathrm{X}\end{array}$} & \multirow{2}{*}{$\begin{array}{c}\text { Others } \\
\mathrm{X}\end{array}$} \\
\hline How I feel? (Affective & "Faces' game" & & & \\
\hline ToM) & Mirror & Emotions - expression, cause & $\mathrm{X}$ & \\
\hline & Smileys Recognition & Emotions - expression & & $\mathrm{X}$ \\
\hline & Puzzle & Emotions - expression, cause & & $\mathrm{X}$ \\
\hline & $\begin{array}{l}\text { Pictorial Book - "The color of } \\
\text { emotions" }\end{array}$ & $\begin{array}{l}\text { Emotions - expression, cause, } \\
\text { intensity }\end{array}$ & & $\mathrm{X}$ \\
\hline \multirow[t]{5}{*}{$\begin{array}{l}\text { What do I believe? } \\
\text { (Cognitive ToM) }\end{array}$} & Hidden objects (deceptive task) & $\begin{array}{l}\text { Perspective taking } \\
\text { Belief } \\
\text { Attention }\end{array}$ & $\mathrm{X}$ & \\
\hline & $\begin{array}{l}\text { Prototypical boxes with unexpected } \\
\text { content - e.g. Smarties box with } \\
\text { pencil inside }\end{array}$ & $\begin{array}{l}\text { Perspective taking } \\
\text { Belief } \\
\text { False belief } \\
\text { Attention } \\
\text { Knowledge } \\
\end{array}$ & $\mathrm{X}$ & \\
\hline & "Mirror images" & $\begin{array}{l}\text { Visual perspective taking } \\
\text { Perspective taking } \\
\text { Attention }\end{array}$ & $\mathrm{X}$ & \\
\hline & $\begin{array}{l}\text { Cartoons: Extract of "Snow White" } \\
\text { - e.g. Snow White thinks she sees } \\
\text { crocodiles while it is a wood. }\end{array}$ & $\begin{array}{l}\text { Perspective taking } \\
\text { Belief } \\
\text { False belief } \\
\text { Intentions } \\
\text { Knowledge } \\
\end{array}$ & & $\mathrm{X}$ \\
\hline & $\begin{array}{l}\text { Pictorial Book - "The wolf may be } \\
\text { here" }\end{array}$ & $\begin{array}{l}\text { Belief } \\
\text { False belief }\end{array}$ & $\mathrm{X}$ & $\mathrm{X}$ \\
\hline \multirow{4}{*}{$\begin{array}{l}\text { Why this feeling? (I)? } \\
\text { (Affective ToM) }\end{array}$} & Level 3 of Howlin et al. program & Emotions - Causes & & $\mathrm{X}$ \\
\hline & $\begin{array}{l}\text { Game - "Marion, Simon and their } \\
\text { emotions" }\end{array}$ & Emotions - Expression, Causes & & $\mathrm{X}$ \\
\hline & $\begin{array}{l}\text { Cartoons: Extract of "The Jungle } \\
\text { Book" - e.g. A girl seeks Moogly } \\
\text { and feels fear when she saw an } \\
\text { animal. }\end{array}$ & Emotions - Expression, Causes & & $\mathrm{X}$ \\
\hline & Pictorial Book - "Happy, Angry" & Emotions - Expression, Causes & & $\mathrm{X}$ \\
\hline \multirow[t]{4}{*}{$\begin{array}{l}\text { Why this feeling? (II)? } \\
\text { (Affective ToM) }\end{array}$} & $\begin{array}{l}\text { Game - Tintin and the four } \\
\text { emotions }\end{array}$ & Emotions - Expression, Causes & & $\mathrm{X}$ \\
\hline & Game - Guess why? & Emotions - Expression, Causes & & $X$ \\
\hline & Pictures - Feelings & $\begin{array}{l}\text { Emotions - Expression, Causes, } \\
\text { Consequences }\end{array}$ & & $X$ \\
\hline & Pictorial Book - "Huge Angry" & $\begin{array}{l}\text { Emotions - Expression, Causes, } \\
\text { Consequences }\end{array}$ & & $\mathrm{X}$ \\
\hline \multirow[t]{2}{*}{$\begin{array}{l}\text { My beliefs and me? (I) } \\
\text { (Cognitive ToM) }\end{array}$} & Game - Mental Simil & $\begin{array}{l}\text { Perspective taking } \\
\text { Belief } \\
\text { False belief } \\
\text { Intentions } \\
\text { Knowledge } \\
\text { Pretend } \\
\text { Attention }\end{array}$ & & $\mathrm{X}$ \\
\hline & $\begin{array}{l}\text { Cartoons: Extract of "The little red } \\
\text { riding hood". - She thinks that she } \\
\text { will see a grandmother while it is } \\
\text { the wolf. }\end{array}$ & $\begin{array}{l}\text { Perspective taking } \\
\text { Belief } \\
\text { False belief } \\
\text { Knowledge } \\
\text { Attention } \\
\text { Visual perception }\end{array}$ & & $\mathrm{X}$ \\
\hline
\end{tabular}




\begin{tabular}{|c|c|c|c|c|}
\hline & $\begin{array}{l}\text { Game: Acting the change of } \\
\text { location task }\end{array}$ & $\begin{array}{l}\text { Perspective taking } \\
\text { Belief } \\
\text { False belief } \\
\text { Knowledge } \\
\text { Attention } \\
\text { Visual perception } \\
\text { Intention }\end{array}$ & & $\mathrm{X}$ \\
\hline & $\begin{array}{l}\text { Pictorial Book - "Giant are you } \\
\text { here?" }\end{array}$ & $\begin{array}{l}\text { Perspective taking } \\
\text { Belief } \\
\text { False belief }\end{array}$ & $\mathrm{X}$ & $\mathrm{X}$ \\
\hline \multirow[t]{3}{*}{$\begin{array}{l}\text { How to react after? } \\
\text { (Affective ToM) }\end{array}$} & Game-Guess why? & $\begin{array}{l}\text { Emotions - Causes and } \\
\text { Consequences }\end{array}$ & & \\
\hline & $\begin{array}{l}\text { Level } 4 \text { of Howlin et al. (2011) } \\
\text { program }\end{array}$ & $\begin{array}{l}\text { Emotions - Causes and } \\
\text { consequences } \\
\text { Desire }\end{array}$ & & \\
\hline & $\begin{array}{l}\text { Pictorial Book - "The wolf who } \\
\text { domesticates his emotions" }\end{array}$ & $\begin{array}{l}\text { Emotions - Causes and } \\
\text { Consequences }\end{array}$ & & \\
\hline \multirow[t]{4}{*}{$\begin{array}{l}\text { My beliefs and me? (II) } \\
\text { (Cognitive ToM) }\end{array}$} & $\begin{array}{l}\text { Level } 5 \text { of Howlin et al. (2011) } \\
\text { program }\end{array}$ & $\begin{array}{l}\text { Emotions - Causes and } \\
\text { consequences } \\
\text { Desire } \\
\text { Belief } \\
\text { Intentions }\end{array}$ & & $\mathrm{X}$ \\
\hline & Game: "Mental Simil" & $\begin{array}{l}\text { Perspective taking } \\
\text { Belief } \\
\text { False belief } \\
\text { Intentions } \\
\text { Knowledge } \\
\text { Pretend } \\
\text { Attention }\end{array}$ & & $\mathrm{X}$ \\
\hline & Game: "Statue" & $\begin{array}{l}\text { Visual perception } \\
\text { Perspective taking } \\
\text { Attention } \\
\text { Knowledge }\end{array}$ & $\mathrm{X}$ & \\
\hline & $\begin{array}{l}\text { Pictorial Book - "The hand of the } \\
\text { witch" }\end{array}$ & $\begin{array}{l}\text { Perspective taking } \\
\text { Belief } \\
\text { False belief }\end{array}$ & & $\mathrm{X}$ \\
\hline \multirow{3}{*}{$\begin{array}{l}\text { Booster and integrative } \\
\text { session } \\
\text { (Affective and } \\
\text { Cognitive ToM) }\end{array}$} & Thermometer of emotions & $\begin{array}{l}\text { Emotions - Expression, Causes, } \\
\text { Consequences }\end{array}$ & $\mathrm{X}$ & \\
\hline & Table of concepts & All mental states & $\mathrm{X}$ & \\
\hline & Craft - Mask of emotions & Emotions - Expression & $\mathrm{X}$ & \\
\hline
\end{tabular}


Appendix D: "ToM program for children" - Objectives and techniques

\begin{tabular}{|c|c|c|}
\hline & Objectives & Techniques \\
\hline General & $\begin{array}{l}\text { - Support the child's socio-emotional } \\
\text { development (understanding and regulation of } \\
\text { emotions) } \\
\text { - Understanding mental states of child or of } \\
\text { various protagonists } \\
\text { - Understand the combination of affective and } \\
\text { cognitive mental states }\end{array}$ & $\begin{array}{l}\text { - Use of key questions } \\
\text { - Asking children's justification } \\
\text { - Immediate feedback, differentiated according to } \\
\text { child's responses and the specific mental state } \\
\text { - Explanation of the correct response and of the } \\
\text { general principle } \\
\text { - Repetition of tasks } \\
\text { - Discussions about affective and cognitive } \\
\text { - Use of various terms related to mental states } \\
\text { - Connections with child's own experience, } \\
\text { - notably by asking, "Did this happen to you?" } \\
\text { - Subgroups training to enhance their learning by } \\
\text { hearing or correcting the other children of their } \\
\text { group }\end{array}$ \\
\hline $\begin{array}{l}\text { Relating to } \\
\text { affective } \\
\text { and/or } \\
\text { cognitive } \\
\text { ToM }\end{array}$ & $\begin{array}{l}\text { Affective ToM } \\
\text { - Understanding desires } \\
\text { - Recognition of own and other's facial emotions } \\
\text { (sadness, joy, fear, anger) following } \\
\text { developmental order: photographic facial } \\
\text { recognition; schematic facial recognition; } \\
\text { situation-based emotions; desire-based } \\
\text { emotions; belief-based emotions } \\
\text { - Understanding of causes and consequences of } \\
\text { own and other's emotions. } \\
\text { Cognitive ToM } \\
\text { - Understanding perspective taking following } \\
\text { developmental acquisition: simple perspective } \\
\text { taking; complex perspective taking; seeing } \\
\text { leads to knowing; true belief prediction; false } \\
\text { belief. } \\
\text { - Understanding own and other's beliefs and } \\
\text { false beliefs } \\
\text { - Understanding intentions, knowledge, pretend, } \\
\text { thinking, attention, and visual perception. } \\
\text { Combination of mental states } \\
\text { - Understanding Desire-Based Emotion, } \\
\text { Perception-Based Belief, Perception-Based } \\
\text { Action Task Standard False Belief, Belief- and } \\
\text { Reality-Based Emotion and Second Order } \\
\text { Emotion }\end{array}$ & $\begin{array}{l}\text { - Semi-open key questions: } \\
\text { - "How does he feel?" } \\
\text { - "Why does he feel?" } \\
\text { - "What will he do?" } \\
\text { - Identification of desires } \\
\text { - Identification of emotions } \\
\text { - Identification of causes of emotions } \\
\text { - Identification of consequences of emotions } \\
\text { - Judgement about emotional reaction } \\
\text { Identification of appropriate reaction to } \\
\text { emotional situations } \\
\text { - Denomination of deceptive objects and } \\
\text { experimenter's demonstration of the distinction } \\
\text { - between appearance and reality } \\
\text { - deception inducing change of location games or } \\
\text { - Demonstration of mirror pictures } \\
\text { - "Whi-open questions: } \\
\text { - "What does he believe?" } \\
\text { - "What does it look like?" } \\
\text { - Identification of beliefs and false beliefs } \\
\text { - Identification of the difference between desires, } \\
\text { - Intentions and beliefs } \\
\text { states }\end{array}$ \\
\hline
\end{tabular}

\section{Copyrights}

Copyright for this article is retained by the author(s), with first publication rights granted to the journal.

This is an open-access article distributed under the terms and conditions of the Creative Commons Attribution license which permits unrestricted use, distribution, and reproduction in any medium, provided the original 